\title{
CHAPTER 6 \\ FEATURES OF INTERCONNECTION \\ AND INTERREACTION OF PARADIGM SHIFTS \\ IN THE MODERN ECONOMY AND THE FORMATION \\ OF NEW THEORETICAL APPROACHES \\ TO THE FIRM ANALYSIS
}

\section{Horniak O. V.}

\section{INTRODUCTION}

Shifts in the modern economy occur in the face of various factors that have a contradictory impact on economic processes. But it is unconditional that the shift is a result of the action of certain forces, as well as a factor influencing all elements of the economic system at different levels. At the micro level, it is seen when, by contributing to paradigm shifts in the economy to improve efficiency and increase profits, the enterprises are creating new conditions of competition and a new environment for their activities, which, in turn, completely change them. The latter are forced to use innovation (technological, product, organizational) in order to provide their competitive advantages.

The firm often faces the dilemma: to buy the necessary goods, to use outsource services, or to produce them by its own efforts? By asking this question, we turn to the works of R. Coase and O. Williamson, as well as to the incomplete contracts theory. According to these approaches, market deficiencies mainly explain the use of the firm's mechanism as well as vertical integration. However, in the early 1970s G. Richardson ${ }^{1}$, the forerunner of the competency-based approach to the firm, questioned the Coase's dichotomy "market-to-firm" by introducing an intermediate category of "inter-firm cooperation". This theoretical issue has become more practical over time as firms' strategies have changed since the 1990s. A Fordist firm, relatively integrated and maintaining traditional subcontracting relationships with its major suppliers, begins to focus on its core competencies and modify its coordination mechanisms with

\footnotetext{
${ }^{1}$ Richardson G. The organization of the Industry. The Economic Jornal. 1972. Vol. 82.
} 
suppliers. Over time, the company-network is preferred. The development of this new organizational form restores theoretical questions about the firm's boundaries.

The study of changes in the economy and the theoretical justification of their impact on the firm are important and relevant, because they provide an opportunity to uncover the relationships between processes and phenomena that occur at different levels of the economy and are crucial for the prospect of development of all elements of the economic system. The formation of new methodological and theoretical approaches in modern theory is based on the fact that processes occurring at the micro level have priority values, and the firm is at the center of modern research areas

\subsection{Organizational forms of economic activity and their theoretical justification}

When setting up the co-operation problem in the economy, G. Richardson distinguished two types of market relations: on the one hand, the market transactions, and, on the other hand, co-operation transactions. The first is interpreted by the hypothesis proposed by neoclassical economics, according to this theory the relationship between firms is determined by the opposition of supply and demand for homogeneous products. The price information is only required under these conditions.

However, in reality, many client-to-supplier relationships are partly "outside the market", that is, fit into G. Richardson's category, which he called "cooperative transactions", since products under these conditions do not exist before exchange. There are two possible options: the product exists either in the form of an order from the client firm, and the supplier begins its production, or in the form of the demand expressed by the client, and then the manufacturer and the client together form its concept for production. In these two cases, the supplier must agree to certain contract liabilities to the customer, in particular, quality control. There is no confrontation between supply and demand, which is distinctive for standardized and homogeneous products. In accordance with the mentioned above, it is necessary to distinguish homogeneous activities and support that are represented as a set of knowledge, skills, experience and qualifications. Firms will strive to specialize in activities in which their competencies will provide competitive advantages. With 
respect to complementary activities, they reflect the different phases of the production process and should therefore be coordinated.

The division of labor among market, firm and inter-firm cooperation under these conditions changes. From a theoretical point of view, if you do not require any specific competence, then there is no limit to the expansion of firm coordination. However, it does not work this way in reality, since the expansion of firm coordination is limited by the fact that complementary activities are not always homogeneous. With such activities, the firm faces a dilemma: do it by itself or involve the others. In this case, there are two options. For activities that do not require ex ante coordination, the appeal to the market is justified because it will ensure the coherence of the plans between the organizations due to the large number of potential suppliers. On the contrary, for very close complementary activities, ex ante coordination between organizations is necessary, and firms should cooperate.

G. Richardson's approach allows for a deeper analysis of economic reality, which makes it possible for the category of cooperation to distinguish two forms of its organization between the main firm and its suppliers. It is about vertical quasi-integration and indirect quasiintegration. In the case of vertical quasi-integration, the customer fully defines the concept of the product and the transmission of information takes place vertically. This complies with the conditions of subcontracting. Indirect quasi-integration is formed when the concept of the product arises in the process of cooperation between the customer and the manufacturer, during which the customer clearly defines the functional characteristics of the product and the manufacturer realizes his/her wishes in the production process. Until the 1980s of the twentieth century the model of vertical quasi-integration prevailed in the economy, and from the period of 1980s - 1990s the model of indirect quasiintegration began to change it. This meant the emergence of a new organizational form: a firm-network.

The theoretical understanding of these complex contradictory relationships between paragigm shifts in the economy and changes in entrepreneurial structures makes it possible to develop a theory of the firm that has been largely reworked and reconsidered in recent decades.

The impact of shifts on the firm can be traced by referring to the concepts that make up the theory of the firm. There are many different theoretical approaches, but traditionally there are three of them, since most 
researchers agree that a single model of the firm is not yet built ${ }^{2}$, but each approach has some gains in developing it.

The first approach combines the concepts that form the traditional (conventional, technological) theory of the firm. It is regarded as a manufacturing function, and its size is explained by the effect of scale and the benefits of integration. In this theory, the firm is managed by the owner, its purpose is to maximize profits in the conditions determined by the market. This approach has evolved in classical economic theory. It can be used to explain, to some extent, the effective size of production that are shaped by shifts in the modern economy, but not by changes in business structures. At the same time, this area of research has formed a stable theoretical construction of the firm, which consists of the following assumptions: the purpose of the firm is the profit maximization, which is a uniquely determined value; the firm is a "black box", the most important parameters in which are input (resources) and output (products), free access to information that is free of charge; rationality of behavior and decisions ${ }^{3}$. This theory of the firm is easy to mathematize, which provides it with supporters and gives the opportunity to constantly update by using the achievements of mathematical analysis, but its disadvantage is that it cannot explain the activities of real firms. It is an element of the partial equilibrium theory and provides an opportunity to predict changes in prices that result from changing conditions of their formation ${ }^{4}$. Therefore, its abstractness is both its strengths and weaknesses.

The second approach presents theories that consider the firm as a network of long-term contracts. It is being developed within the framework of a new institutional economic theory based on the study of transaction costs. Fundamental transformation of O.E. Williamson ${ }^{5}$ is its core. It concerns the specific situation in trade (ex ante), which after a specific investment (ex post) becomes a bilateral monopoly. As a result, the interdependence of firms increases, which can lead to third-party benefits. As a result, the investment process is halted, it has a negative impact on firms. The way out is become a long-term contract that

\footnotetext{
${ }^{2}$ Furubotn EG, Richter R. Institutes and economic theory. Achievements of a new institutional economic theory. St. Petersburg. Ed. the house of St. Petersburg. state. Universities. 2005. 702 p.; Claude H. The New Economy: Forms of Discovery, Causes and Consequences. K. Tucson. 2006. 306 p.

${ }^{3}$ Горняк О.В. Теорії фірми. Навч. посібник. Одеса. Астропринт, 2010.

${ }^{4}$ Махлуп Ф. Теории фирмы: маржималистские, бихевиористские и управленческие. В кн. Вехи экономической мысли. Т. 2. Теория фирмы. Под ред. В.М. Гальперина. СПб.: Экономическая школа. 1999. $524 \mathrm{c}$.

5 Вільямсон О.Е. Економічні інституції капіталізму. Фірми, маркетинг, укладання контрактів. К.: АртЕк, 2001. 472 с.
} 
guarantees them a reasonable return and promotes specific investment. Shifts in the modern economy have provided flexibility in production and marketing, which has significantly reduced the specificity of investment, but on the other hand, increasing the value of human capital in the development of the modern economy requires increasing the specificity of investment, as the creative component of economic processes increases. This approach also has some limitations in explaining a truly functioning enterprise, since integrated units based on long-term contracts may be a legal entity (vertically integrated structures of the type of concerns, or horizontally integrated type of the Japanese keiretsu), and may not be of such a form (virtual organizations, clusters, strategic alliances).

The third approach combines theories that develop the idea of contracts imperfection, their incompleteness, which enables firms to evolve in the face of dynamic change and uncertainty. The so-called modern firm fits the context of these theories. Unlike the traditional one, it has such features $^{6}$ as a predominance of intangible assets in the capital structure; identifying human capital as a major element of assets; flexibility in relations with employees, partners and clients; staff mobility within the firm; abandoning tight control over consumers and suppliers of the firm.

In recent decades, the modern theory of the firm is very rapidly developing. Studies of the process of its formation and development are quite fully presented in the works of B. Holmstrom and J. Tirole ${ }^{7}$, as well as D. Hay and D. Morris ${ }^{8}$, but after their release, the dynamics of economic change has accelerated significantly, so there is a need for theoretical reflection and justification of the impact of these changes on the functioning of real firms and the theory of the firm.

Each of the approaches considered has its advantages and disadvantages, explores one or the other side of the enterprise, and in the end they do not confront, but complement each other, forming a holistic picture of the firm. But the impact of changes in the modern economy on the firm most is fully reflected by the approaches of the new institutional economics. Considering that the impacts are contradictory, they vary for different enterprises of different spheres and industries, it is difficult to determine the general development trends.

\footnotetext{
${ }_{7}^{6}$ Socio-economic efficiency: the US experience. Landmark for globalization. M. Science, 2002. 360 p.

7 Holmstrom B.R. and J. Tirole. The Theory of the Firm. In: R. Schmalensee and R.D. Willing, ads., Hand book of Industine Organisation Amsterdam: North-Holland 1989, 1, 63-133.

${ }^{8}$ Хэй Д., Моррис Д. Теория организации промышленности. В 2-х томах. Т-2. СПб. ГУ экономики и финансов. Высшая школа экономики, 1999. 592 с.
} 
Features of the development of the theory of the firm and its theoretical justification in the context of fundamental shifts in the economy can be presented in the form of a table.

Table 1

The development of the firm under the influence of changes in the modern economy and its theoretical justification

\begin{tabular}{|c|c|c|c|}
\hline $\begin{array}{l}\text { Characteristics } \\
\text { of the modern } \\
\text { economy }\end{array}$ & $\begin{array}{c}\text { Priorities } \\
\text { of modern } \\
\text { production }\end{array}$ & $\begin{array}{c}\text { Features } \\
\text { of the firm's } \\
\text { development }\end{array}$ & $\begin{array}{l}\text { Theories } \\
\text { and researchers }\end{array}$ \\
\hline Servization & $\begin{array}{l}\text { The dominance of } \\
\text { the service sector } \\
\text { in the structure of } \\
\text { social production }\end{array}$ & $\begin{array}{l}\text { The role of } \\
\text { intangible assets is } \\
\text { increasing. Human } \\
\text { capital is a major } \\
\text { element of assets. } \\
\text { Outsourcing }\end{array}$ & $\begin{array}{l}\text { E. Penrose's New } \\
\text { Resource-Based } \\
\text { Theory. The Theory } \\
\text { of Core } \\
\text { Competencies by } \\
\text { C. Prahalad and } \\
\text { G. Hamel }\end{array}$ \\
\hline Individualization & $\begin{array}{l}\text { Focusing on } \\
\text { individual } \\
\text { consumer } \\
\text { requests and } \\
\text { changing demand }\end{array}$ & $\begin{array}{l}\text { Customer loyalty: } \\
\text { building long lasting } \\
\text { relationships with } \\
\text { your most profitable } \\
\text { customers. Trust } \\
\text { between } \\
\text { manufacturers and } \\
\text { customers }\end{array}$ & $\begin{array}{l}\text { The Behavioral } \\
\text { Theory of the Firm } \\
\text { by H. Simon, } \\
\text { R. Cyert, J. March }\end{array}$ \\
\hline Virtualization & $\begin{array}{l}\text { Internet } \\
\text { technology. } \\
\text { Information } \\
\text { Communication } \\
\text { Technology }\end{array}$ & $\begin{array}{l}\text { Flexible contracts } \\
\text { with employees } \\
\text { (freelancing), } \\
\text { partners, structural } \\
\text { units }\end{array}$ & $\begin{array}{l}\text { The Agent Theory by } \\
\text { A. Alchian, } \\
\text { H. Demsetz. } \\
\text { The Contract Theory } \\
\text { of the Firm by } \\
\text { O.E. Williamson. }\end{array}$ \\
\hline Networkization & $\begin{array}{l}\text { Organizational } \\
\text { changes at the } \\
\text { micro level. } \\
\text { Formation of the } \\
\text { inter-firm } \\
\text { networks }\end{array}$ & $\begin{array}{l}\text { Participation in the } \\
\text { functioning of } \\
\text { network structures: } \\
\text { alliances, focal nets, } \\
\text { clusters }\end{array}$ & $\begin{array}{l}\text { The Evolutionary } \\
\text { Theory of Economic } \\
\text { Change by } \\
\text { R. Nelson, S. Winter. } \\
\text { The Transaction Cost } \\
\text { Theory by R. Coase, } \\
\text { O.E. Williamson. }\end{array}$ \\
\hline
\end{tabular}

Source: developed by the author 


\subsection{Servization and individualization of the modern economy and development of the theory of the firm}

In the development of the modern economy, its directions are of particular importance, such as servization (increasing the role of services and changes in the structure of production and the product itself); individualization (orientation of productions to a specific consumer, to changes in consumer requests); virtualization (transfer of producerconsumer relations to the Internet network); networkization (functioning of enterprises as participants in network entities, which contributes to their competitiveness). These processes change social production significantly, bringing its structure and organizational forms in line with the objective processes of development of the modern economy.

The development of the service economy began in the United States in the 60s of the twentieth century, 1979 was considered as the year of its birth in France and the United Kingdom, it was marked by a sharp increase in employment in this field. In the 1990s, the servization of the economy began in Southeast Asia and gradually spread across the continent ${ }^{9}$. The material basis of the service processes and their acceleration was made by information technologies, development of satellite communications, computer networks. Changes in the structure of human needs, in professional specialization, in the skills and skills of employees also played an important role in this process. Servization of the economy is not only a quantitative change in the structure of social production (share of the service sector in GDP, in the number of the employed persons, in resources), but also qualitative changes due to the fact that the service sector becomes the main source and main driving force of economic growth and prosperity.

As the service sector is represented by a wide variety of activities, their contribution to its dynamization is different. According to research, the growth of the service sector is ensured by the professional services sector: financial, insurance, advisory. Their share in GDP is constantly increasing. In the group of developed countries it is $20-30 \%{ }^{10}$. Empirical studies indicate a relatively high intensity of investment activity in this area. Due to this factor, as well as due to the intensive use of information

\footnotetext{
${ }^{9}$ Вітренко А.О. Сервісна економіка: Теорія, сучасні виклики та глобальні тренди. Київ : Знання. 2016. 413 c

${ }^{10}$ Вітренко А.О. Сервісна економіка: Теорія, сучасні виклики та глобальні тренди. Київ : Знання. 2016. C. 134-135, 140.
} 
and communication technologies, the service economy provides a significant increase in labor productivity.

Within the service economy in a post-industrial society, the resource such as knowledge and information, which is an important element of intangible assets, is of particular importance to modern firms.

Servization of the economy transforms the activities of firms significantly and gives them new characteristics, among which there is the growing role of intangible assets in ensuring their competitive advantage. In the structure of the firm's assets intangible assets increase their share and begin to outweigh tangible assets. The main element of the company's assets is human capital. The firm's activity is organized around its core competencies, other activities are out of the company through outsourcing mechanisms. All these processes are explored by a new resource-based theory, initiated by E. Penrose ${ }^{11}$. An important component of this theoretical concept is the theory of core competencies. Its developers G. Hamel and C. Prachalad identified the main directions of development of firms in the new conditions ${ }^{12}$.

They are related to value creation and to the management of performance gaps, adaptability and capabilities. The performance gap is an analysis of the firm's achievements over a period of time in improving quality, reducing costs, decreasing production and sales cycles, logistics, staff rightsizing, improving profitability, the administrative system. The restructuring is the necessary tool here. The study of changes in the industry, the formation of a brand portfolio, the choice of channels of product promotion, the directions of transformation and development of a new business model are necessary when there is the gap in adaptability. As a result, the organizational form is changed, which makes it possible to increase the adaptive capacity of the firm. The gap in opportunities is represented by the creation of new types of business, the development of new markets, the development of strategies and the search (creation) of the appropriate resource base $\mathrm{e}^{13}$.

This approach is particularly important in a time of fundamental paradigm shifts in various industries and fields. They testify to the growing role of gap management, in adaptability and capabilities above all. For

\footnotetext{
${ }_{11}^{11}$ Penrose E. The Theory of the Growth of the Firm. Oxford Basil Black Well, 1959.

${ }^{12}$ Hamel G., Prachalad C.K. The Core Competence of the Corporation. Harvard Business Review. Mai-june. 1990.

${ }^{13}$ Прахалад С. К., Фаэй Л., Ренделл Р. Создание ключевых компетенций и их использование. В. кн. Портер М., Самплер Дж., Прахалад С. К. и др. Курс МВА по стратегическому менеджменту. Москва : Альмина Бизнес Букс, 2004. С. 358-359.
} 
making a breakthrough in a particular industry, it is not enough to just outpace competitors in quality, cost, profitability, etc. The example of the computer industry confirms that gap management should be carried out in all three directions. It is known that for decades IBM has been the undisputed leader in this field. It is a vertically integrated structure from development to sales. In the early 2000 s, the computer industry began to disintegrate, and as IBM did not anticipate these changes, Intel, Compaq and Microsoft became the first in new segments of the industry. As a result, Intel received dominance in producing of microprocessors, Microsoft in operating systems, Lotus in software applications. Distribution channels have changed, as well as the major retailers: Computerland, Sears ${ }^{14}$.

Similar changes occur in most industries. Many of these changes are fundamental and even change the clearly defined boundaries of the industry. The multimedia business would be an example, where it is difficult to differentiate between consumer, office and professional products and generally draw lines of distinction between activities.

In today's context, the very paradigm of competition is changing, which is manifested in such forms as competition in commodity markets (price, market segment, quality), competition for dominance in key products (leadership in the development of new functional characteristics and speed of product development), and competition for key competencies (the ability to create new types of business based on a creative combination of skills and competencies). Winning the latter provides the strategic competitive advantage of the firm, so key competencies in modern business play a crucial role in its development.

The key competencies are combinations of different technologies, cooperative learning and the ability to disseminate information. The examples of such competencies include miniaturization at Sony, network marketing at AT\&T, focus on usability at Apple, billing convenience at regional Bell companies ${ }^{15}$.

The modern economy is characterized by individualization, focused on the needs of a particular consumer. As a result, the firm's main competitive advantage is customer loyalty. This applies especially to firms operating in the manufacturing industry, but is gradually expanding to

\footnotetext{
14 Прахалад С.К., Фаэй Л., Ренделл Р. Создание ключевых компетенций и их использование. В. кн. Портер М., Самплер Дж., Прахалад С.К. и др. Курс МВА по стратегическому менеджменту. М.: Альмина Бизнес Букс.2004, 360 с.

15 Прахалад С. К., Фаэй Л., Ренделл Р. Создание ключевых компетенций и их использование. В. кн. Портер М., Самплер Дж., Прахалад С. К. и др. Курс МВА по стратегическому менеджменту. М.: Альмина Бизнес Букс, 2004. С. 363-364.
} 
other industries and areas. The way to achieve this is to build a corporate strategy not in the direction of capturing the largest part of the market, but in winning the loyalty of the most profitable customers, which is ensured not only by the supply of goods of appropriate quality, but also by minimizing the costs associated with its operation. The firm must control the distribution channels and the post-sale service. Trust relations between producers and consumers play a special role in today's economy.

To increase trust through the control of distribution channels, some American companies have exclusive contracts with trading companies that sell the products under their brand. This is typical for manufacturers of home appliances, computers, cars, soft drinks, etc. This factor greatly increases the opportunities of the firm not only in terms of the sale of goods or services, but also in terms of increasing consumer confidence, which is supported by trust in trading firms, which operate with the customers and are close to them (Foxtrot, Eldorado, Epicentr, Metro).

The study of such a phenomenon of modern economy as individualization fits into the context of the behavioral theory of the firm, developed by H. Simon, R. Cyert, J. March ${ }^{16}$. The firm's interpretation as a coalition of agents, which also includes the firm's customers (clients), theoretically substantiates not only the firm's dependence on its customers, but also reveals mechanisms for building trust, adjustment of goals, and building long-term relationships.

Within the concept of a firm as a coalition, the individualistic behavior of its members is explored. If management school exponents have identified only two participants in the analysis of the enterprise (managers and shareholders), then behaviorists are significantly expanding the boundaries of the firm, including all those related to its activities in the coalition: employees, shareholders, managers, customers, suppliers, creditors, etc. Behavioral analysis clearly traces the approaches in terms of psychology and some separation from the economic concepts of individual behavior. At the same time, the concept of behavior reveals how the differentiated decisions of managers, who realize their own interests and different goals, shape the enterprise as a coherently organized system that functions effectively.

The main mechanism here is individual behavior, based on satisfaction with the result. The satisfaction principle is based on personal

${ }^{16}$ Саймон Г. А. Теория принятия решений в экономической теории и науке о поведении. В кн. Вехи экономической мысли. Т.2. Теория фирмы. СПб.: Экономическая школа, 1999. С. 54-72; Cyert R. M., March Jc. A Behavioral theory of the firm. Prenfice Holl, 1963. 
or professional motives and takes into account the level of decision-makers' requests. In contrast to full rationality, which is a tool for the analysis of simple situations and forms a neoclassical approach to the firm, H. Simon substantiates the concept of bounded rationality ${ }^{17}$, which is a more effective tool for studying the behavior of the firm, especially in the face of environmental uncertainty and interdependent enterprise behavior.

The motives for individual actions are based on the wishes, needs and knowledge of the manager. Actions to achieve the goal are taken after meeting the needs at one or another level of requests. It is determined, in turn, by the level of requests of this manager in the previous period; the level of requests of other managers in making such decisions; predicting the situation and getting out of it; effectiveness of previous decisions of the manager. By setting the level of requests in this way, the manager makes decisions, taking into account alternative decisions and their consequences, and almost does not consider decisions related to the enterprise strategy. And since the determination of levels of requests and satisfactory decisions is subjective, behavioral theory does not develop a methodology for summarizing the principles of enterprise behavior. Efforts to bring behavior models closer to the real enterprises significantly complicate these models and narrow their scope. But, despite these shortcomings, the behavioral theory played an important role in the development of the theory of thefirm and prepared the basis for the emergence of theories of the enterprise strategy.

\subsection{The relationship between virtualization and networkization of the economy and its theoretical justification}

The virtualization of the economy is associated primarily with the advent and implementation of computer technology, and, therefore, the creation of such concepts as a virtual object, virtual reality. In virtual reality, material substance is replaced by correlations and functions to which a person is "attracted by consciousness"18. As a result, the subject substance becomes unnecessary, in the process of virtualization material things are depreciated, become nothing. At the same time, virtual objects are generated by and interact with objects of reality. The virtual economy is related to the production of information and knowledge, its basis is formed

\footnotetext{
${ }^{17}$ Саймон Г.А. Теория принятия решений в экономической теории и науке о поведении. В кн. Вехи экономической мысли. Т.2. Теория фирмы. СПб.: Экономическая школа, 1999. С. 54-72.

18 Скотний П.В. Економіко-теоретичне знання в парадигмі методології монографія. Дрогобич, 2011. С. 311.
} 
by creative work that cannot be standardized, formalized or simplified. It is connected with self-development, with the production of itself. Value categories in the virtual economy are losing their value. Relationships and relationships in the virtual economy are realized in the process of convergence, not on the principles of competition. In addition, they are formed horizontally, not vertically. Virtual economy is formed in cybernetic space, in networks of information establishments. Its influence on the firm is reflected in the formation of horizontal management structures, in the atomization of the enterprise, when the units become autonomous in the flexibility of contracts with employees (development of freelancing) and partners. Representatives of the agent theory are engaged in theoretical substantiation of influence of these processes on the firm ${ }^{19}$ and contract theory of the firm ${ }^{20}$.

The theoretical substantiation of the firm as a nexus of contracts is based on the ideas of A. Alchian and H. Demsetz ${ }^{21}$. However, the real creators of the concept of the firm as the nexus of contracts were M. Jensen and $\mathrm{W}$. Meckling, who developed the ideas of previous authors in their work $^{22}$. The theoretical basis of this concept is the theory of motivation. It sets out to determine which organizational form maximizes the drive of individuals: firm or market.

According to A. Alcian and H. Demsetz, the market a priori is the most effective form of organization in terms of maximizing effort and labor intensity, given the high correlation between individuals' remuneration and their productivity, whereas a firm-like organization makes no sense of existence. So they ask the question: what is the difference between a business owner and his employees and buyers of products, i.e. market partners? The answer is: the difference in having a central contract agent in a collective production process, rather than in a larger authoritarian governing or disciplinary authority. This means that the only advantage of the firm over the market is the authors distinguish in the synergistic effect of teamwork, which is best provided by the firm due to the contractual structure.

\footnotetext{
${ }^{19}$ Алчиан А., Демсец Т. Производство, информационные издержки и экономическая организация. В кн. Истоки: экономика в контексте истории и культуры. Москва. Издат. дом ГУ ВШЭ. 2004. C. 166-207.

${ }^{20}$ Клодт Х. Нова економіка: форми вияву, причини і наслідки. К. Таксон. 2006. 306 с.

21 Алчиан А., Демсец Т. Производство, информационные издержки и экономическая организация. В кн. Истоки: экономика в контексте истории и культуры. Москва. Издат. дом ГУ ВШЭ. 2004. C. 166-207.

${ }_{22}$ Jensen M. C., Mecling W. H. Teoty of the Firm: Managerial, Behavior, Agency Cocts and ownership Structure. Journal of Finansial Economies. 1976. N 4. P. 305-360.
} 
The manager of the firm, as the central manager, in addition to the right to monitor income, profit, has some other rights: the right to contract with suppliers, including owners of labor, the right to monitor the behavior of members of the company, determine the remuneration, tasks, instructions, the right to change the composition of the team, etc.

Summarizing the approaches of A. Alchian and H. Demsetz, we can say that they define the firm as a system of assessment of individual capabilities and motives, which arises when the market is unable to provide the collective production and optimal form of organization, which corresponds to the classic managerial, entrepreneurial capitalist firm, which brings them closer to the theory of motivation.

M. Jensen and W. Meckling, when continuing the researches of A. Alchian and H. Demsetz, focused on contractual relationships that, in their view, shape the essence of a firm in its interractions not only with suppliers but also with customers, banks, governmental organizations, etc.

The study of such situations is conducted within the framework of the theory of motivation. It appeared in the 1980s and is based on two fundamental hypotheses. It assumes that agents are economically rational and that their ability to account for all possible options is endless as they have access to all the information they need. However, unlike neoclassical homo economicus, principals, due to the asymmetry of information, are under-informed compared to their potential agent partners.

As a result, agents, as in O.E. Williamson's works, become opportunists, i.e. those who are ready to deceive others for the sake of their own interests. However, the theory of motivation limits the role of opportunistic behavior, believing that it is neutralized by agents' desire to comply with the terms of the contract. Therefore, the future must be considered without surprises, given the oversight of contract performance (sometimes called "autoperformance"). In addition, the theory assumes the existence of a third party who oversees the performance of contractual obligations (courts). This contractual approach goes beyond the firm's disciplinary concept: the contract must force agents, employees, suppliers, etc. to fulfill their commitments made in advance (ex ante).

Based on the theory of motivation, some researchers (including P. Milgrom and J. Roberts) have developed their theory of the firm ${ }^{23}$. They tried to synthesize it from three approaches: the Coase's authority-based

\footnotetext{
${ }^{23}$ Милгром П., Робертс Д. Экономика, организация, менеджмент. СПб.: Экономическая школа. 1999. В 2-х томах. Т. 1.470 с. Т. 2. 424 c.
} 
aproach, the theory of incomplete property-based contracts, and the the theory of motivation itself based on the reward system. In this view, the company uses a combination of tools that should encourage employees to act in the interests of the employer, that is, the search for the best possible combination of these three exposures of endogenous origin by the employee, also taking into account three factors of exogenous origin, capable to influence the previously mentioned combination: uncertainty about the future, the degree of specificity of the assets being exchanged, and the cost of evaluating employee performance.

This approach is typical for defining the virtual organization, in which partner companies use the skills and experience together to reduce costs. They also help one another to gain access to the markets they have mastered. Within the virtual organization there are both vertical and horizontal quasi-integrations. The concept of vertical quasi-integration involves the collaboration of teams consisting of specialists with different functions. Virtual teams work without restrictions in space and time, as well as in the company itself. Their connections are provided by technological networks. They are engaged in the development and management of products, services and processes in close collaboration, which results in the formation of a feedback system, which in turn becomes the basis of mutual learning and maintaining a high level of quality. Changes in the market modify the teams, so virtual corporations are flexible and "fluid", and they change their configuration quickly. At the same time, the ability to integrate and reformat without long negotiations quickly implies a constant search for companies that are close in terms of business processes, organizational culture and information systems ${ }^{24}$. It is provided by a virtual network platform, the formation and development of which reflects the processes of networkization.

Networkization of the modern economy is its important characteristic. Although in the broad interpretation of any human activity is a network interaction, it is the current stage of the network development as a mechanism for coordinating the interactions of economic agents. The formation of networks at the micro level has led to changes in organizational forms of network interaction: strategic alliances and clusters. Network cooperation in modern conditions is based on the widespread use of information and communication technologies and

\footnotetext{
${ }^{24}$ Шерешева М.Ю. Форми сетевого взаимодействия компаний. Курс лекций. М.: Изд. дом ГУ Высшей школы экономики, 2010. С. 222.
} 
provides high competitive advantages by reducing transaction costs, leveling opportunistic behavior, the use of specific assets, relational contracts, the benefits of cooperation and trust.

The theoretical basis for the processes of networkization of the modern economy was formed within the framework of the new institutional economic theory. R. Coase started researching the firm as an economic agent with a complex internal structure that has individual features that determine its position in the industry, competitive advantages and motives for cooperation with other firms ${ }^{25}$. R. Coase defined the firm and the market as alternative mechanisms for coordinating economic activity. The criterion for choosing one or the other is the amount of transaction costs. Network cooperation also reduces them, which is why transaction cost theory is an important tool for exploring networks and network economics. An important role in the comparative analysis of the effectiveness of different organizational forms was played by the study of O.E. Williamson, who deepened the analysis of transaction costs, structured them, introduced the idea of bounded rationality, which belonged to $\mathrm{H}$. Simon, into the theory of transaction costs, developed the theory of asset specificity, distinguished varieties of contracts (classic, neoclassical, relational). It is the relational contracts that play a decisive role in establishing the interaction of economic agents, and therefore in the formation of the network.

An important contribution to the study of intercompany interaction was the evolutionary theory of economic change ${ }^{26}$, which studies not a single firm, but a population of firms with different levels of competitiveness, interacting and developing. The level of the competitive advantages of each firm depends on the ability to use their competencies, as well as the competencies of other firms, which should gradually become routine and provide the best result. Research on the interaction of firms in the population indicates the possibility of using the achievements of the evolutionary theory of economic change to study the networks where this interaction and the mechanisms of its coordination are the basis.

In the economy, the process of forming networks is gradually performed in the process of disintegration and separation from the integral Fordist diversified firm. There are three stages of this process.

\footnotetext{
${ }^{25}$ Коуз Р. Природа фирмы. В кн.: Природа фирмы. Под ред. О.Е. Уильямсон и С. Дж. Уинтера. Москва. Дело. 2001. С. 33-52.

${ }_{26}^{26}$ Нельсон Р.Р., Уинтер С. Дж. Эволюционная теория экономических измерений. М.: «Финстатинформ». 1990.
} 
At the first stage in the 70-80s of the twentieth century firms have begun to disintegrate to counteract the negative effects of integration and diversification strategies. At the second stage, firms began to carry out structural externalization, which required the identification of specific competencies that differentiated them from others. This is an offensive phase in which firms pursue an active policy across all lines of business and provide them with appropriate financial solutions that aim to save and increase profitability through the use of merger, acquisition and externalization processes ${ }^{27}$. The latter process provided them with an opportunity to pass some of the risks on to clients: the risk of overexpenditure associated with reinvestment and the risk of underproduction associated with underinvestment. At the same time, customers can also reduce their costs by optimizing, since a supplier, while producing for multiple clients, provides economies of the scale and can reduce costs, which has a positive impact on the customer, and can also use cheaper labor in other countries. In addition, externalization enables the firm to realize the benefits of firm division of labor that provide a concentration of resources on those activities that require less cost and increase the competitiveness of the firm. It is about developing the competencies of a firm that externalize activities that are not close to the standard one.

\section{CONCLUSIONS}

Existing theories of the firm in the most general form can be represented by three trends: traditional, contractual, evolutionary (modern). Each of them explains different aspects of the firm's activity at certain stages of its economic development. The modern economy is taking on new features, so its every structural element is also changing. First of all, it concerns the firm. Servization of the economy implies an increase in the role of intangible assets in the structure of its capital. Human capital and competencies are a major factor in generating competitive advantage. Competencies that are removed from core competencies are outsourced. The individualization of the economy is based on the focus of production on individual customer requests and constant changes in demand. In such circumstances, the company is forced to build stable long-term relationships with the most profitable clients. In this regard, increasing trust

\footnotetext{
27 Нельсон Р.P., Уинтер С. Дж. Эволюционная теория экономических измерений. М.: «Финстатинформ». 1990.
} 
between manufacturers and consumers is a crucial prerequisite for successful operation.

Economy virtualization is ensured by the development of the Internet, information and communication technologies. Firms under these conditions enter into flexible contracts with employees, partners, structural units, which changes the firm, its organizational structure and form. Networkization of the economy is manifested in the growing role and importance of various inter-firm and inter-organizational networks, participation in which provides significant competitive advantages for firms.

The tendencies of development of modern economy and their influence on the firm are theoretically grounded in the concepts of new resource-based theory, transaction costs theory, behavioral theory, core competencies theory, the agent theory, contract theory and evolutionary theory of economic change. The combination of methodological principles and theoretical approaches of these theories provides an opportunity to form a modern theory of the firm, which reflects the peculiarities of the development of real firms and theoretical achievements in their understanding and fits into the context of modern economic theory.

Thus, shifts in the modern economy, new trends in its development determine the fundamental changes in the functioning of firms and the emergence of new directions in the theory of the firms. The theoretical understanding of the processes that take place at different levels of the economy, in turn, provides an opportunity to determine the development prospects, ways to solve emerging problems and make decisions on ensuring efficiency, well-being, economic security.

\section{SUMMARY}

In today's economy, under the influence of a number of factors, cardinal shifts occur at all its levels. Particular attention needs to be paid to the processes taking place at the micro level, as in the last decades the role of the firm in providing the competitive advantages of the national economy, in raising the well-being of the population and solving social problems has significantly increased. New trends in the economy, which determine the direction of change and the depth of shifts, significantly affect, above all, the firm, its structure and forms. Servization, individualization, virtualization, and networkization have brought to life the appropriate organizational forms and structures of firms that require theoretical substantiation, the development of new theoretical approaches 
to the analysis of the firm and the definition of priority directions of its development in various industries and spheres of economy. Particular attention should be paid to the relationship between changes in the economy and in the activities of the firm, the effects of these changes on the development of theoretical competencies and models of the firm. This section explores the peculiarities of such relationships and interactions, identifies the directions of change and priorities of modern production, the development of the company and theoretical approaches to its analysis. This made it possible to substantiate the feasibility of forming a new theory of the firm in the context of shifts in the modern economy and the development of a new paradigm of economic theory.

\section{REFERENCES}

1. Richardson G. The organization of Industre. The Economic Jornal. 1972. Vol. 82.

2. Фуруботн Э.Г., Рихтер Р. Институты и экономическая теория. Достижения новой институциональной экономической теории. СПб. Изд. дом СПб. гос. ун-ва, 2005. 702 с.

3. Клодт Х. Нова економіка: форми вияву, причини і наслідки. Київ : Таксон, 2006. 306 с.

4. Горняк О.В. Теорії фірми. Навч. посібник. Одеса : Астропринт, 2010.

5. Махлуп Ф. Теории фирмы: маржималистские, бихевиористские и управленческие. В кн. Вехи экономической мысли. Т. 2. Теория фирмы. Под ред. В.М. Гальперина. СПб.: Экономическая школа, 1999. $524 \mathrm{c.}$

6. Вільямсон О.Е. Економічні інституції капіталізму. Фірми, маркетинг, укладання контрактів. Київ : АртЕк, 2001. 472 с.

7. Социально-экономическая эффективность: опыт США. Ориентир на глобализацию. Москва : Наука, 2002. 360 с.

8. Holmstrom B.R. and J. Tirole. The Theory of the Firm. In: R. Schmalensee and R.D. Willing, ads., Hand book of Industine Organisation Amsterdam: North-Holland 1989, 1, 63-133.

9. Хэй Д., Моррис Д. Теория организации промышленности. В 2-х томах. Т-2. СПб. ГУ экономики и финансов. Высшая школа экономики, 1999. $592 \mathrm{c}$.

10. Вітренко А.О. Сервісна економіка: Теорія, сучасні виклики та глобальні тренди. Київ : Знання, 2016. 413 с. 
11. Penrose E. The Theory of the Growth of the Firm. Oxford Basil Black Well, 1959.

12. Hamel G., Prachalad C.K. The Core Competence of the Corporation. Harvard Business Review. Mai-june, 1990.

13. Прахалад С.К., Фаэй Л., Ренделл Р. Создание ключевых компетенций и их использование. В. кн. Портер М., Самплер Дж., Прахалад С. К. и др. Курс МВА по стратегическому менеджменту. Москва : Альмина Бизнес Букс, 2004. С. 357-382.

14. Саймон Г.А. Теория принятия решений в экономической теории и науке о поведении. В кн. Вехи экономической мысли. Т. 2. Теория фирмы. СПб. : Экономическая школа. 1999. С. 54-72.

15. Cyert R. M., March Jc. A Behavioral theory of the firm. Prenfice Holl. 1963.

16. Скотний П.В. Економіко-теоретичне знання в парадигмі методології : монографія. Дрогобич, 2011. 408 с.

17. Алчиан А., Демсец Т. Производство, информационные издержки и экономическая организация. В кн. Истоки: экономика в контексте истории и культуры. Москва : Издат. дом ГУ ВШЭ, 2004. C. 166-207.

18. Jensen M. C., Mecling W. H. Teoty of the Firm: Managerial, Behavior, Agency Cocts and ownership Structure. Journal of Finansial Economies. 1976. N 4. P. 305-360.

19. Милгром П., Робертс Д. Экономика, организация, менеджмент. СПб : Экономическая школа, 1999. В 2-х томах. Т. 1. 470 c. T. 2.424 c.

20. Шерешева М.Ю. Форми сетевого взаимодействия компаний. Курс лекций. Москва : Изд. дом ГУ Высшей школы экономики, 2010. 339 c.

21. Коуз Р. Природа фирмы. В кн.: Природа фирмы. Под ред. О.Е. Уильямсон и С. Дж. Уинтера. Москва : Дело. 2001. С. 33-52.

22. Нельсон Р.Р., Уинтер С. Дж. Эволюционная теория экономических измерений. Москва : 300 «Финстатинформ», 1990.

\section{Information about the author:} Horniak O. V.

Doctor of Economic Sciences, Associate Professor, Head of the Department of Economics and Entrepreneurship, Odessa I.I. Mechnikov National University, Ukraine 